\title{
Governance in Hungarian family businesses
}

\author{
Attila WIESZT \\ Corvinus University of Budapest, Hungary
}

\begin{abstract}
:
Aim: A large-scale, exploratory survey had been conducted on the whole population of family businesses in Hungary in 2017/18 concentrating on the heterogeneity of the family business population. This paper presents the findings of this survey focusing only on the governance practices of the Hungarian family businesses.

Design / Research methods: Two questionnaire were asked from a sample of Hungarian family businesses in the form of computer-assisted phone interview. This sample is based on probability sampling of a larger database representative to the Hungarian population of business organization in terms of annual revenue, geographical location and industry. Questions were formulated considering models of family involvement, socio-emotional wealth, succession, governance and professionalization.
\end{abstract}

Conclusions / findings: Hungarian family businesses succeed in involving a growing number of family members into the company which also positively relates to the business performance of the firms. The developmental patterns of their governance practices reflect their increasing level of professionalization. However, they can hardly involve external, non-family professionals into the Top Management Team, which may be crucial especially for the further growth of medium-sized firms. Their family governance concentrates rather on operatively bridging family and company, and not on planning the maintenance of long-term family control.

Originality / value of the article: The paper delivers both information on the heterogeneity of the Hungarian family businesses from a governance-related point of view, and show direct, practical implications regarding the family business governance system. Its results can be of interest both for family business owners, researchers and consultants.

Keywords: governance structure, family business, family business governance, family governance, Hungary.

JEL: G30, G38, G39

Correspondence address: Attila WIESZT, Corvinus University of Budapest, Hungary. E-mail: attila.wieszt@uni-corvinus.hu

Received: 05.11.2018, Revised: 30.12.2018, Accepted: 02.01.2019

doi: http://dx.doi.org/10.29015/cerem.786 


\section{Introduction}

Although country-level surveys had been realized in other countries during the last decades in family business research, there has been no similar comprehensive survey conducted before in Hungary on the whole population of family businesses. Previous efforts targeted only at a specific regional or industrial set of family businesses or concentrated on SMEs.

With the aim to contribute to fill this gap, the Center of Family Business at the Corvinus University Budapest implemented a large scale, exploratory survey on the Hungarian family business profile at the end of 2017. In this paper I present the findings of this survey focusing only on the governance practices of the Hungarian family businesses.

\section{Governance in family businesses}

\subsection{Definition of governance in family business}

There are no widely accepted definition for governance either for family or nonfamily businesses (Gersick-Feliu 2014). Governance in general refers to both structures and processes by which organizations are led, controlled and owned (Gnan et al. 2015; Huse 2009). These structures and processes (Uhlaner et al. 2007) ensure both the prevailence of the interests of the owners throughout the operation of the business and that interests of all stakeholders are also taken into consideration.

In family business research, the scope of governance is always a bit wider than in general management research: beyond linking shareholders' interests and expectations of critical stakeholders with the firms' strategic and operative management, the relationship between different kinds and levels of family involvement into the governance and business performance of the company is also of primal concern here (Goel et al. 2014). My study applies the notion of governance based on this latter, wider perspective.

It implies that when inspecting governance systems at Hungarian family businesses, I aim at observing not only the mechanisms of corporate and subsequent 
ownership governance, but also how family and relationship between family and the company is governed. From now on I label this approach as family business governance.

\subsection{Relevance of family business governance}

The reason why family business governance requires additional attention as compared to the governance practices of non-family businesses is morefold.

Firstly, standard assumptions of agency (principal-agent) and stewardship theories being the most frequently applied theoretical frameworks in family business governance are not always applicable (Van Essen et al. 2015; Schulze et al. 2001, Miller, Le Breton-Miller 2006; Siebels, zu Knyphausen-Aufseß 2012). The assumption of the presence of large, unified family blockholders acting jointly without personal battles, supervising and controlling top managers of the firm continuously with the same, unchanging competency and motivation can not always be maintained. Since my aim here is merely to exhibit the relevance of investigation of governance at family businesses, and not to present major theories of governance, instead of disentangling below the bundles of assumptions according to theories, I rather raise possible issues when these assumptions are hardly applicable and point at their governance implications.

Families often do not behave like blockholders: misaligned interests can lead to hidden or open conflicts between family members and family branches. These diverging interests can be induced by personal differences based on particular needs of individual and family life cycle: employment, career or financial needs may be highly different from each other based on the specific life cycle stages, which individuals occupy (Chrismann 2004). Family dynamics may also cause rapture among members of the supposedly blockholder team: personal conflicts between siblings, or parents and the children can escalate to an extent when the tension may split up their unified group into different parts. Furthermore, situational differences can lead to disagreement among family owners too: family members (branches), who are more actively involved into the operation of the company, possess more accurate information on the firm and as employees can have different interests 
regarding the planning and implementation of the strategy than other, more passive family members, who are less-informed on the company (Schulze et al. 2001). All in all, diverging interests of family members and branches necessarily lead to different levels of risk-aversion, preferred time horizon of the implementation of the strategy, different level of identification with the company and differing personal emotional attachment to the firm (Chua et al. 2009).

Furthermore, family members may not be able to carry out professional control and supervision (Lubatkin et al. 2007a; Goel et al. 2014). Their intention to maintain transgenerational control may lead to a behavior, when parents favor family members over other professional, but non-family individuals. Children from the upper generations may also be rather biased to maintain their family heritage, that is the long-term family ownership of the company (Dawson-Parada 2019). They are determined to preserve dominant control of the family which in return can lead to biased decisions on overestimating the performance of family members or choosing incompetent non-family managers. An additional factor can be mentioned here: if family members have an absolute power inside the firm, without any governmental constraint, highly-trained, but non-family professionals will perceive less room for creating a career in the organization and hence will be less motivated to join the company.

As a solution for the above mentioned problems, literature suggests the introduction of governmental mechanisms differing from the ones of the non-family businesses. At non-family businesses, governance concentrates on the alignment of goals and interests between the owners and the managers. Whereas at family-owned companies, governmental structure should be designed to introduce and maintain family preferences inside the company and to curb the otherwise unconstrained power of the family owners (Miller, Le Breton-Miller 2006; Koeberle-Schmied et al. 2014).

The second reason why family businesses need special governmental solutions that contrasts to non-family businesses can be connected to the limited functionality of traditional governance mechanisms in family-owned businesses (Anderson-Reeb 2004; Carney et al. 2013; Van Essen et al. 2015; Bammens et al. 2011). 
The Board of Directors as a governance mechanism fulfils both controlling and supervising functions. However, family businesses are less likely to establish such body since managers whom should be monitored by this mechanism are family members or non-family, but affiliated directors. Although family control can certainly be represented through this board, but this plenum is less open to involvement of external, independent professionals, who may exert a control on the overusage of the power of the family inside the company and who may introduce specific, professional knowledge into the firm (Bammens et al. 2011).

Concentrated ownership of the family at family businesses, as a next possible governance mechanism can function well in controlling non-family managers. However, it also means a drawback when diverging interests of family owners (or between family owner and an external minority owner) arise either regarding the strategy of the firm or regarding ownership because it can not ensure the management and harmonization of misaligned interests of these parties (Memili 2011).

Performance-based payment is a traditional tool for the alignment of the interests of owners and managers - but in family businesses, such compensational systems are less likely to be installed, and even if they are, one of the most motivating item, providing shares for the managers is missing as a consequence of family intention of maintaining dominant control of the firm in long-term (PindadoRequejo 2015).

Family businesses are also immune to some of the main external governance mechanisms to some extent. They are less impacted by the threat of external take over since family has a concentrated ownership and aims at preserving it for longterm (Carney et al. 2013; Van Essen et al. 2015). Competition in their main markets will also exert direct pressure on family businesses to a smaller extent since they either search and occupy a niche where they are able to tide over harder market times (Van Essen et al. 2015). Besides, their primal concern is not to react to immediate requirements of the market but to maintain traditions in their product line as well. Thirdly, they are less directly exposed to managerial labor market which would set clear standards for the underperforming managers and would reward overperformers because there are family members among leaders of the company 
who are usually not menaced by giving them the sack. (Schulze et al. 2001; GomezMejia et al. 2001)

According to the literature, decreasing functionality of the above mentioned governance mechanisms can be remedied if family businesses augment the fulfilment of those weakened functions by imposing clear governance regulations (Gersick, Feliu 2014; Memili 2011; Bammens et al. 2011).

Beyond the problems of the standard governance assumptions and the curbed functionality of some traditional governance mechanisms, there are further reasons why family businesses require their own governance solutions. Whereas the main points of the above arguments originate from the principal-agent theory, from the stewardship theory and from the resource based view of family businesses, the ensuing factors can be linked to social capital theory and to structural considerations of the family business system.

Firstly, family businesses rely on more informal governance than non-familyowned businesses. Some argue that it is because of the overlapping character of the subsystems that constitute the family business system (Goel et al. 2014; Gersick, Feliu 2014). Others point at the importance of the social interactions both among family members when working for the company and among family members and other stakeholders that underline and define the framework of any governance mechanism. It implies that the differentiation between contractual and relational governance at the case of family businesses is not simply a choice of approach or followed research theory - both kind of governance should be inspected at the same time in a unified and integrated way (Miller, Le Breton-Miller 2011).

Secondly, since family as a system should also carry out specific functions for the business system to operate adequately, family also needs governance. This governance supports the preservance of family unity behind the ownership of the company, and maintains and manages the relationship between the family and the firm (Suess 2014).

There are other considerations relating to the significance of governance at family businesses specifically in Hungary. According to the institutional argumentation, in emerging economies, like Hungary, the enforcement of the agency contracts incurs more cost which implies a more concentrated firm ownership 
(North 1990; Dana-Ramadani 2015). Putting the concentrated ownership and the absence of effective external governance (because of the ineffectively operating market institutions) together, one can argue that conflicts between dominant and minority shareholders will be more frequent, than in family businesses from developed countries where ownership, control and operative leadership are more separated and there are effective legal mechanisms that protect owners (DanaRamadani 2015).

Other authors also raise that family businesses may thrive in the presence of institutional weaknesses because they form groups in which they can allocate capital for the members of the group who are in need and also create a secure market for each other where both the buyers and the sellers know each other (Dinh, Calabrò 2019).

Both of the above arguments imply well-functioning family business governance that can manage internal and external challenges, which the firm faces in this special, partially underdeveloped institutional environment.

The final theoretical argument supporting the relevance of inspection of family business governance is connected to the social contingency theory (Le BretonMiller, Miller 2009). According to this theoretical framework, the extent to which agency or stewardship assumptions prevail in governance depends on economic, psychological and sociological considerations (Goel et al. 2014). The degree of social embeddedness of stakeholders into the family and the self-control of the owner and the values endowed by the family will influence the adoption and domination of either agency rationale or stewardship attitudes - which also hints at the importance of country-specific investigation of governance (Le Breton-Miller, Miller 2009).

\subsection{Classification of family business governance mechanisms}

The structure of governance interlaces the whole family business system and as such, it also becomes part of this larger system (Gallo, Kenyo-Rouvinez 2005; Koeberle-Schmied et al. 2014) as a subsystem of the original family business system and called as family business governance system. Henceforth the classification of 
the governance mechanisms which constitute the governance system can be implemented by following the three-circle model (Nordqvist et al. 2014).

The business subsystem has two main governance mechanisms: the Board of Directors and the Top Management Team led by the CEO. Members of the Board of Directors are usually assigned by the owners. The Board fulfils the function of control of the CEO and top managers, and also the supervision of them in form of providing advice and feedback for their work. The CEO and the group of top managers have the function of exercising leadership. In my interpretation here, the function of leading, the leadership means operative management of the company, that is the CEO and the top managers operatively lead the organization according to the strategical goals and guidelines of the owners (Uhlaner et al. 2007; Gersick, Feliu 2014). Prevailence of these governance bodies is also dependent on organizational, market and country factors. In some other classifications, in other business or legal context, Board of Directors is linked to more operative function of leadership, whereas the control and supervisory function is related to a Supervisory Board whose members are chosen by the owners (Bammens et al. 2011; Pindado, Requejo 2015).

The main governance mechanism of the ownership subsystem is the Shareholder's Meeting and it implements the function of owning. The operation and development of the ownership subsystem may be augmented by Family Trusts, which is the tool for financial and estate planning from ownership perspective, and the Family Offices, which also covers the tasks of estate planning but from the point of view of family's wealth management. These are only the main, most frequent governmental tools, there are other possible mechanisms as well, such as limited family partnerships, or different kind of trusts (Gersick, Feliu 2014).

The main governance forum of the family subsystem is the Family Council. It recruits family members, and its main purpose is to design and maintain the relationship between the firm and the family with two corresponding basic functions: persistently bridging the family and the business on one hand, and planning and ensuring the maintenance of the long-term family control over the company (Carlock, Ward 2001). 
More complex families may also install Family Meetings (also called as Reunion or Assembly) for ensuring the education and information of all family members on business matters, the identification of the members with the business, and all in all, the family unity behind the ownership and operation of the company. Family Committees may also be established for more focused tasks which body belong to the family subsystem. Family Constitution (also known as Code of Conduct or Family Protocol) records all of the formal agreement of the Family Council (and the Assembly and Committees) that relates to the relationship of the company and family (Carlock, Ward 2001).

The limitation of this categorization can be connected to the critics of the threecircle model. Firstly, the model reifies that each subsystem and its respective governance tools are existing. However, in reality, subsystems and their governance mechanisms can sometimes not be identified in the clear-cut way of the model, they may merge together (Gersick et al. 1997). Secondly, analytical separation of the subsystems may cover the fact that they also complement each other, and their governmental mechanisms are also pieced together (Koeberle-Schmied, Caspersz 2013). For instance, Family Council works strongly together with the Board of Directors, sometimes can even take over certain competencies from the Board of Directors. Thus all in all, three-circle model is adequate for inspecting governmental structures, but one should be aware of these limitations when evaluating the structure and functionality of the whole governance system.

These are the reason why instead of applying only the classification of governance mechanisms based on the three-circle model, I also focused on the functions these mechanisms fulfil. Based on my above definition of the governance and classification of governance mechanisms, functions of governance at a company and at its shareholder's group include ownership, control and supervision, and leadership (Huse 2009; Gnan et al. 2015). Other necessary function originating from the family-ownership are the preservation of family unity regarding the firm and the maintenance of family-firm relationship (Gersick et al. 1997, Carlock, Ward 2001).

One further advantage of this additional approach is that it offers a conceptual framework to grasp and analyze the evolution of governance bodies (KoeberleSchmied, Caspersz 2013). As a business organization becomes family company 
from a sheer entrepreneurship, family members get employed, the idea of long-term family ownership emerges, all of the above listed functions based on basic needs of the subsystems should be satisfied. It may mean that there will not be separate Family Council, Board of Directors, Supervisory Board and Shareholders Meeting because the company is small and simply there is no need for a sophisticated governance structure: all important decisions will be discussed by the weekly or monthly meetings of the founder and his or her spouse or children. Later on, as both the family and the company grows and becomes more complex, specific functions, which can not be fulfilled anymore without separated, dedicated governance mechanisms: family meetings and top management meetings may be differentiated, and external, non-family leaders may also be invited into the top management meetings. Applying primarily the fundamental functions for the inspection of governance structure means that instead of using the concepts of a clear-cut, wellstructured governmental system based on the three-circle model, I can inspect how the form of functional fulfilment is changing by time and how the governance system's structure itself evolves.

All in all, the research applied this ,functionally aided" classification of governance system based on these main, fundamental functions.

\section{The research design and methodology}

The research on governance practices at Hungarian family businesses was conducted as part of a larger exploratory survey on the Hungarian family business profile at the end of 2017 and beginning of 2018.

There was no comprehensive survey conducted before on the whole population, previous efforts targeted only at specific parts of the family businesses (usually only those belonging to SMEs). Thus previously we had only incomplete and to some extent inconsistent informations available on the Hungarian population of family businesses.

Instead of focusing on the comparision of family and non-family businesses, this research inspected merely family-owned companies and concentrated on their 


\section{GOVERNANCE IN HUNGARIAN FAMILY BUSINESSES}

heterogeneity. In this question the research followed the recent string of the literature which emphasizes that the dichotomized framework of family vs. nonfamily businesses can be misleading since it inherently reifies the non-existing homogeneity of family businesses (Zellweger et al. 2013). Besides, it may simplify the notion of family and can also overlook the whole range of company resources generated by family involvement (Jaskiewicz, Gibb Dyer 2017). Henceforth, turning away from observing why they are different from non-family businesses, the survey aimed at exploring how they are different from each other: what kinds of internal groups their population has and how they differ regarding their internal processes. Thus all in all, the research questions were formulated as follows: what are the demographics of the Hungarian family businesses and how can their profile in terms of composition, structure, and internal processes be described.

The overall aim of the research was to acquire a general picture on the Hungarian situation that can raise interest for the family business population in social sciences and that can also set the basis of later surveys. The specific aim was to explore a „bird's view” on the different needs and internal dynamics of the target population.

Since - as mentioned above - we had rather limited and insufficient informations on the internal characteristics of the Hungarian family business group, a cautious, double-level research design had been applied by conducting two, separate interviews with family businesses. The first, shorter questionnaire asked for general informations regarding the family influence on the firm and performance outcome. The second, longer interview that was conducted around a month later aimed at gaining more detailed data on chosen internal processes.

Although the survey research was exploratory in nature, it followed widely accepted and well-tried theoretical concepts and models from the literature on which the development of its two questionnaires for the two interviews was banked. This process also ensures that the results are comparable with findings of other previous research projects from other countries and can be used for future comparision as well.

The first questionnaire consists of three parts. Beyond basic questions regarding the position of the interviewees, its first segment relates to the operative definitional 
levels of family businesses (Sharma 2004; Jaskiewicz, Gibb Dyer 2017) (identification of the firm as family business, presence of dominant control of the family/families, ownership ratio of the family/families, succession intentions) with the exception of the importance of family values in the firm. The second and third section connect to the mainstream research stance that puts variables of family influence together with performance of the family business as outcome variable, and inspect how family involvement of different kind and extent may exert impact on various possible outcome variables (Anderson, Reeb 2003; Carney et al. 2013; Van Essen et al. 2015; Pindado, Requejo 2015). The second part of the survey asked about the age of the firm, how many family members and generations are involved into the operation of the company as employee, how many family member is part of the Top Management Team, what is the ratio of family and non-family members in this team, if they have Supervisory Board, what is ratio of family members, and whether they have family CEO. The question regarding succession intentions from the first segment was also regarded as belonging to this second part.

The third section of the first questionnaire asked questions regarding the performance outcome of the company in three dimensions: in the change direction of annual turnover, market position and profitability. Although these answers are based on self-assessment and were not compared with the real data (since they are often hardly available), experiences from management research show high correlation of the two data sets from self-reports and the formal company reports (Ling, Kellermanns 2010; Sieger et al. 2013; Stanley 2017).

The above variables on direct family involvement not only reflects family influence, but also mean significant governmental settings and configurations which thus in the theoretical framework on which the questionnaire is based can be directly connected to performance variables of the firm. I analyse the collected data and evaluate the survey's findings from this, governance perspective.

The second questionnaire stepped beyond the above „blackbox model” of family businesses that links the impact of the family and the firm-level outcome, and aimed at focusing on the processes that may directly establish the connection between them. 
As a critic to the underemphasized family effect in the research based on management research perspective, it is a uniform recommendation of the literature to reassess and to refine the monolithic notion of direct family involvement (Holt et al. 2017), and initially consider family's goals and aspirations instead, and break it down to financial and non-financial goals as inputs into the existence and operation of the family-owned company. Following these recommendations, I turned to the research efforts on socio-emotional wealth which notions connects exactly the nonfinancial aspirations of the family with the firm they own (Gómez-Mejía et al. 2011; Debicki et al. 2016). It is important to note that by definition, the relationship between socio-emotional wealth, internal processes of the company and the economic outcomes are not lineal, but rather circumvent. Socio-emotional wealth is derived from the ownership of the company, and this wealth in turn influences decisions of family members regarding the relationship of the firm and the family and regarding the operation of the company (Debicki et al. 2016). There are various robust and well-tested measurement methods (Debicki et al. 2016; Berrone et al. 2012). I applied a recent one from the possible batteries, the REI scale (Hauck et al. 2016) which is an enhanced, thus more targeted and shortened version of the FIBER scale (Berrone et al. 2012).

The next sections of the second questionnaire collected data from internal processes of the inspected family-owned businesses. The research observed succession, governance and - to a much lower extent - professionalization (Dekker et al. 2015), and - with one question - the innovational activity of the firms. There had been many various other potentional topics to be focus on: e.g. strategy of the family business system, leadership, valuation of the firm, external institutional settings and family businesses or estate planning among others. The choice of topic reflects the research focal points of the Corvinus Center of Family Business at Corvinus University of Budapest, where I work, which in turn indicates the core issues of the Hungarian context. Here I introduce only the relevant, governance part of the questionnaire.

Since the research aimed at almost the whole population and I also knew, that greater part of the Hungarian family businesses are small and medium sized company (ratio of large firms among all of Hungarian business entities is less than 
$1 \%$ ), furthermore they are typically first or second generational, and because of the less complex family and company subsystems, their governance systems are also less differentiated. Therefore the governance mechanisms of their systems are more easily grasped by complementing the traditional classification of the three-circle model with the above mentioned functional terms: 1. to lead the business (corresponding with the mechanism of CEO and management team), 2. to control the firm (the mechanisms of Board of Directors), 3. to own the company (the mechanisms of Shareholder's Meeting), 4. to maintain family unity and relationship of family and company (the mechanism of Family Council).

When formulating the question regarding the fulfillment of the function of leading, the interview subjects were asked whether their firms have the body where operative decisions are done and if yes, in which location (at firm, at home, or at an external venue) and what characteristics feature its operation (frequency of these meetings, number of participants, ratio of family members, nature of family relationship to the CEO, frequency of discussion of possible professional topics). To observe the fulfillment of control of the firm, I asked if there is a forum for making decisions on non-operative and strategical issues (frequency of these meetings, number of participants, ratio of family members, nature of family relationship to the CEO). Regarding the function of owning (Shareholders Meeting), I asked about the main forum on the ownership of the company. Finally, as the fourth function is concerned, I asked about the existence of forum on connected to the relationship between the family and the company, on the possible topics of the council, on possible formal or informal regulations regarding the firm-family relationship and I also directly asked wether they have Family Constitution or not.

\section{Data collection}

A large, original database of Hungarian business organizations was purchased. This database was representative to the whole population regarding their size, industry and location. We filtered it according to three criteria. Firstly, companies having the legal form of individual proprietorships and secondly, companies 


\section{GOVERNANCE IN HUNGARIAN FAMILY BUSINESSES}

operating in the financial services were excluded. Thirdly, although the survey originally aimed at larger family businesses, since our factual knowledge of the internal distribution of the whole population had been scarce, we decided on setting our zoom wider and targeted at Hungarian family-owned businesses with an annual turnover of between 80 million and 150 billion Hungarian Forints. It means that microbusinesses and lowest segment of small businesses based on annual turnover were excluded from the investigation. The research partner of the Center of Family Business at the Corvinus University of Budapest, a data collector company applied probability sampling from the remaining entries of the filtered database and conducted computer assisted phone interviews on the sampled entries. The data collector called each and every firm from the sample and started the interview based on the first questionnaire. According to the protocol, they asked for an interview with the family leader of the firm, or, as a second best option with a family member in a top manager position.

We wanted to create results that are comparable with the ones of other countries, and had little previous quantitative evidences from Hungary on the general characteristics of the whole population. Thus we defined family businesses in general - along with the international family business literature - as a firm largely controlled by a family with the potential intention and vision of maintaining this control across generations. As an implication of these considerations, for deciding whether a firm contacted throughout the research is family-owned or not, the survey applied a double parallel threshold: first it asked whether the respondent considered itself as a family-owned business and if a family/families has dominant control of the ownership shares. Next it also asked about the specific extent of the ownership and if it exceeds the 50\% ratio. If either of the tresholds (or both) was fulfilled, it regarded the specific firm as family business and included it into the database.

The first database was planned to contain 1,400 family business and was finally created between 2017 October and 2018 January as including 1,415 firms. The second questionnaire ensued the first one approximately a month later between 2017 November and 2018 January from a subsample of 250 firms of the first family business database. This research design ensured that the resulting database is 
representative to the Hungarian family businesses with respect to their size, industry and location.

According to the data collecting protocol, the primal targets were family leaders of the companies. Only if no family member from the Top Management Team was available, an interview with non-family leader of the company was considered, as the second best option. All in all, majority of the respondents was family member (a bit less, than $75 \%$ ).

\section{Results}

\subsection{Descriptive statistics of the sample}

Table 1 depicts the basic descriptive statistics regarding the sample ${ }^{1}$. Classification of companies according to their size was conducted based on the number of persons they employ: small-sized (or small) firms have 50 or less employees, medium-sized (or medium) firms have more than 50, but not more than 250 employees, while those having more than 250 employees were labelled as largesized (large) firms. Around $91 \%$ of the firms is small-sized based on employee number, a bit less than $8 \%$ is middle-sized, and $1 \%$ of them is large-firm. This roughly corresponds to the internal distribution of the whole Hungarian population of business entities. Majority of the firms is second-generational, around 2.55 family members work at the company as an employee, but less, around 2 members are also involved into the top management. Number of employed family members is lower at small firms, peaks at medium firms and decreases again at the large firms (but still to a value which is higher than at small firms). Headcount of Top Management

\footnotetext{
${ }^{1}$ List of involved variables (beyond basic and filter questions): 1) succession intentions, 2) year of foundation, 3) number of family members involved as employee, 4) number of family generations involved into the operation/control of the company, 5) headcount of Top Management Team, 6) number of participants from the Top Management Team who are employees, 7) number of family members in the Top Management Team, 8) presence of Supervisory Board, 9) headcount of Supervisory Board, 10) number of family members involved into the Supervisory Board, 11) family CEO, 12) number of the CEO's generation related to the founding generation, 13) presence of family entrepreneurial history (previous enterprises owned by direct family lineage), 14) specific period of operation of possible previous enterprises, 15) ownership ratio of the family.
} 
Team and number of family members involved into the Top Management Team also follows the same dynamics: they start at a lower value at small companies, set their highest value at medium firms and become smaller again at large ones. Interestingly, considering the ratio of family members in the Top Management Team, it constantly increases: thus contrary to the fact that at large firms, both the headcount of the Top Management Team and the number of involved members is smaller than at medium firms, fall of headcount is steeper and henceforth the ratio is higher.

Table 1. Descriptive statistics of the governance-related questions of the first questionnaire

\begin{tabular}{|l|c|c|c|c|c|c|c|}
\hline & Average & $\begin{array}{l}\text { Standard } \\
\text { deviation }\end{array}$ & Minimum & Q1 & Median & Q3 & Maximum \\
\hline \hline Ownership ratio & 88.0874 & 26.5083 & 0 & 100 & 100 & 100 & 100 \\
\hline Year of foundation & 1993.7014 & 7.793 & 1900 & 1991 & 1994 & 1997 & 2016 \\
\hline $\begin{array}{l}\text { Number of family members } \\
\text { involved as employee }\end{array}$ & 2.5533 & 1.632 & 0 & 2 & 2 & 3 & 20 \\
\hline $\begin{array}{l}\text { Number of family } \\
\text { generations involved into the } \\
\text { operation/control of the } \\
\text { company }\end{array}$ & 1.7216 & 0.5827 & 0 & 1 & 2 & 2 & 5 \\
\hline $\begin{array}{l}\text { Headcount of the Top } \\
\text { Management Team }\end{array}$ & 2.2925 & 1.3367 & 1 & 2 & 2 & 3 & 25 \\
\hline $\begin{array}{l}\text { Number of family members } \\
\text { in the Top Management } \\
\text { Team }\end{array}$ & 2.1096 & 1.12 & 0 & 1 & 2 & 3 & 15 \\
\hline $\begin{array}{l}\text { Family CEO's generation } \\
\text { related to the founding } \\
\text { generation (if there's one) }\end{array}$ & 1.2337 & 0.447 & 0 & 1 & 1 & 1 & 4 \\
\hline
\end{tabular}

Categorial variables

\begin{tabular}{|l|c|c|c|c|}
\hline & \multicolumn{1}{|c|}{$\begin{array}{c}\text { Highly } \\
\text { probable }\end{array}$} & $\begin{array}{c}\text { Rather } \\
\text { probable }\end{array}$ & $\begin{array}{c}\text { Rather } \\
\text { not } \\
\text { probable }\end{array}$ & $\begin{array}{c}\text { Not } \\
\text { probable } \\
\text { at all }\end{array}$ \\
\hline Succession intentions & 38.95 & 28.93 & 17.24 & 14.88 \\
\hline & & \multicolumn{2}{|c|}{ Yes } & No \\
\hline Is the CEO of the firm a family member? & 96.53 & 3.47 \\
\hline Was (were) there entrepreneur(s) in the direct lineage of the family? & 29.64 & 70.36 \\
\hline
\end{tabular}




\subsection{Results from the first questionnaire - family business profile from the perspective of the governance}

Ordinal logistic regression had been applied to uncover any connection between the variables of family influence and the performance outcome of the firms. I found few connections between these data. Firstly, I had an intuitive result: age of the company has slight positive effect both on change in market position and on profitability of the firm. Secondly, if family succession intentions were strong (but only at that case), it has positive impact on profitability. Thirdly, involvement of one more person into the Top Management Team resulted in significant drop of annual turnover, while involvement of one more family member into the same team has huge positive effect on the annual turnover. The net impact of the latter two effects is still positive, thus the joining of family member can outnumber the negative effect.

One should put an emphasis on the fact that the mathematical-statistical model provided a solution, a functional connection, but it is valid only in the context of the sample: it does not mean that one can involve any chosen number of family members into the business with positive effect. The positive effect rather exists in the set of the observations, and valid only in their context: majority of Hungarian family businesses are owned and maintained by either only the founder-leader (around 10\%) or the dual of the founder-leader and his/her spouse (49\%). Successful involvement of additional family members beyond the founder or beyond the founder and the spouse may be the way to generate growth in the firm and thus family involvement in this interpretation may mean a possible developmental pattern for the Hungarian family businesses.

Furthermore, I can also assume that only those members are involved firstly, who are competent enough, who have the ability to work in the business - but the survey did not differentiate between able and non-able family members. This is another characteristics of the sample which limits the extension of the regression results without any constraint.

Both cluster analysis (CA) and latent profile analysis (LPA) had been conducted on exploring their internal profiles since I intended the research to be explorative in 
nature and again, we hardly have any exact previous information on the population. Although both methods belong to the set of configurational approaches and are analogous inasmuch they identify possible internal groups of the investigated population, the mathematical calculation is different. Some author suggest that LPA is superior in terms of statistical validity (Stanley 2017), since it is supposed to provide more reliable results if the entries in the sample follow normal distribution, and also delivers the number of internal groups without any further computation and valuation (Fraley, Raftery 2002). One should put an emphasis on the requirement of normal distribution which can not be assumed if data are not continuous. The type of cluster analysis applied is the K-prototype cluster analysis, because from the many possible types of CA, it directly was developed for data sets containing both continuous and non-continuous variables (Huang 1998). When at secondary cluster analysis I involved only continuous variables as independent variables, the $\mathrm{K}$ prototype transformed into standard, K-means cluster analysis (Forgy 1965). From the various possible heuristic methods that augment the decision on the number of clusters, I chose the Cluster Elbow Method (Thorndike 1953), since it delivers a valid and well-tried (oldest and most widespread) calculational process (Kodinariya, Makwana 2013) when K-prototype (and K-means) Cluster Analysis is conducted. Establishing the number of groups at LPA was conducted by the Bayesian Information Criterion (BIC).

I conducted two analyses: the first one involved almost all variables of family involvement ${ }^{2}$ from the first questionnaire, including ownership ratio, number of involved generations, number of involved family members, ratio of family members in the Top Management Team, strengths of family succession intentions, year of foundation, presence of family $\mathrm{CEO}$, presence of possible family entrepreneurial

\footnotetext{
${ }^{2}$ I excluded only three related questions of family influence: the ones regarding the possible presence of any Supervisory Board, the headcount of members in this board and number of family members in the board. Calculation of ratio of family members in the Supervisory Board revealed that huge amount of respondents did not understand / misunderstood this question (ratio of family members were larger than 1) thus I decided here on exclusion. Reason behind the large number of misunderstanding might be that the institute of Supervisory Board is less known for Hungarian family business owners due to their relatively lower complexity and smaller size than in other, more developed countries.
} 
history and firm size (in terms of number of employees) and business performance of the firm. Since non-continuous data were also considered here, only k-prototype cluster analysis had been applied. The second analysis which followed the extended model introduced by Stanley et al. contained only number of employees, ownership ratio, year of foundation, number of involved family members and generations and ratio of family members in the Top Management Team - here both K-means CA and LPA were used.

Table 2a. Results of the K-prototype cluster analysis and the latent profile analysis

\begin{tabular}{|c|c|c|c|c|c|c|c|c|c|c|c|}
\hline Cluster & $\begin{array}{c}\text { Number } \\
\text { of items }\end{array}$ & a) & b) & c) & d) & e) & f) & g) & h) & i) & j) \\
\hline $\mathbf{1}$ & 11 & 333 & 4.06 & 0.8 & 95.45 & 4 & 1992.55 & 3.36 & 1.91 & 1 & 2 \\
\hline $\mathbf{2}$ & 189 & 30.6 & 3.72 & 0.91 & 98.5 & 3 & 1993.82 & 2.58 & 1.7 & 1 & 1 \\
\hline $\mathbf{3}$ & 484 & 10.14 & 3.75 & 0.94 & 98.71 & 4 & 1994.04 & 2.48 & 1.71 & 1 & 2 \\
\hline $\mathbf{4}$ & 128 & 15.88 & 3.78 & 0.88 & 35.25 & 3 & 1993.45 & 2.79 & 1.77 & 1 & 2 \\
\hline
\end{tabular}

\section{K-Prototype Cluster Analysis (with Cluster Elbow Method)}

Involved variables: a) firm size (in terms of number of employees), b) economic performance of the firm (aggregated index, value set: between 1-5), c) ratio of family members in the Top Management Team, d) ownership ratio, e) strength of succession intentions (value set: between 1-4), f) year of foundation, g) number of involved family members, h) number of involved generations, i) presence of family CEO, j) presence of possible family entrepreneurial history

Table 2b. Latent Profile Analysis (informational criteria: Bayesean Informational Criteria)

\begin{tabular}{|c|c|c|c|c|c|c|c|}
\hline Cluster & $\begin{array}{c}\text { Number } \\
\text { of items }\end{array}$ & a) & b) & c) & d) & e) & f) \\
\hline $\mathbf{1}$ & 44 & 48.78 & 1995.11 & 2.25 & 1.7 & 0.53 & 14.94 \\
\hline $\mathbf{2}$ & 13 & 70.66 & 1974.48 & 1.71 & 1.97 & 1 & 54.34 \\
\hline $\mathbf{3}$ & 180 & 53 & 1994.67 & 2.39 & 1.74 & 1 & 13.06 \\
\hline $\mathbf{4}$ & 25 & 55.54 & 1991.32 & 3.91 & 1.84 & 0.85 & 50.14 \\
\hline $\mathbf{5}$ & 974 & 100 & 1993.8 & 2.53 & 1.7 & 0.95 & 22.6 \\
\hline $\mathbf{6}$ & 16 & 28.26 & 1995.93 & 5.38 & 2 & 0.6 & 299.33 \\
\hline
\end{tabular}

Involved variables: a) ownership ratio, b) year of foundation, c) number of involved family members, d) number of involved generations, e) ratio of family 
I considered the first computation (K-prototype CA analysis with cluster elbow method) as delivering the base for the analysis, since here I was able to involve all range of variables of family influence including succession intentions, direct governance settings and also the special variable of the presence of family entrepreneurial history originating from the Hungarian context.

Checking the results (Table 2a, b), I have a relatively small group of large companies where item's number is 11 (smaller than the number of large companies in the whole sample). On average, they are overperforming others, they have the highest number of involved family members and also the lowest ratio of family member involvement into the Top Management Team. The second group is somewhere inbetween the large and micro-like small companies regarding their average size. The number of involved family members is around the value of that of the third and fourth groups, but the ratio of family member involvement into the Top Management Team is the highest among the groups. Its average performance value is the lowest one. Interestingly, family entrepreneurial history gets the average value of 1 here, meaning that they have such background on average. At the other end of the pole, the third group with around micro-sized group member companies has the second lowest performance value and the highest ratio of family members in the Top Management Team. It is the most populated category. The fourth group represent firms that are somewhat larger on average than micro businesses, has the highest performance-level among small-sized companies and also the smallest ratio of family members involved into the top management.

All in all, one can state that the analysis splits the population into a very small group of most effectively operating large firms, into a group of least effective „large" small businesses, into a group of „medium” small businesses and into a group of small businesses who are around the edge of being microbusiness. The latter one's headcount adds up to a larger number than the other three's all together.

Putting these results to the ones from the above regression analysis and the descriptive statistics of the internal groups of firms in the sample based on their size, they show a clear picture regarding the Hungarian family business profile from the point of view of family influence and governance. 
Firstly, as micro family businesses become small companies, more and more family member is employed in the firm and also the ratio of family members involved into the Top Management Team is getting higher. The regression analysis showed that this is beneficial for the firm considering the change in annual turnover ${ }^{3}$. In reality it may mean that the growth of the originally founder-led entrepreneurships manifests itself in attracting more family members to the company and to the Top Management Team.

Secondly, these results also reflect the decade-old problem of the Hungarian economy, namely the problem of the missing population of medium-sized firms. Although $7.69 \%$ of the firms from the sample is categorized as medium firm statistically, large part of medium-sized companies looks and behaves as a small business from the point of view of family influence. They involve more family members than smaller firms, but are not really able to decrease the ratio of family members in the Top Management Team or with other word, to attract external professional managers, as large family businesses do.

Thirdly, a small group of large family businesses have the highest average performance, the highest number of employed family members and the smallest ratio of family members in the top Top Management Team. Membership of this group is not necessarily determined by size: not all family businesses that are statistically large show these family influence patterns.

In order to control the above results, I also checked these results with another model, where I involved only continuous variables and applied both CA and LPA to uncover the possible configurations. The classifications of this model seemingly delivered different results: 5 clusters/groups ${ }^{4}$, with partially different headcounts. One of the main tendencies, the continuously increasing number of involved family members can only be partially observed. The other main tendency however is

\footnotetext{
${ }^{3}$ Although regression analysis was calculated for the whole sample involving medium and large firms as well, their weight $(8.75 \%)$ in the whole sample is relatively small. Thus results of the regression analysis are rather descriptive for small firms.

${ }^{4}$ As shown in Table 3, cluster analysis of the variables explored 6 clusters - but one of them contains only one entry from the database. Since the main aim with this secondary calculation was purely to crosscheck the tendencies that had been explored in the first analysis, without any further computation, I considered this one-item cluster as an exception, and regarded only the remaining 5 clusters.
} 
identical - and this tendency is directly rather important from the perspective of the governance: the above statements about the different developmental path of the small, medium and large Hungarian family businesses had also been banked on it. The larger the firm, the smaller the ratio of family members involved into the Top Management Team - that is, the larger the room for engagement of external, nonfamily managers will be.

\subsection{Results from the second questionnaire}

As stated before, the second questionnaire was asked on a subsample of the whole sample, including 251 family businesses where family members were interviewed and only small and medium sized companies got into this subsample.

\section{Table 3. Governance mechanisms and their characteristics - Descriptive statistics}

\section{Top Management Team}

\begin{tabular}{|c|c|c|c|c|c|}
\hline Survey question & Population & $\begin{array}{l}\text { Regular } \\
\text { work } \\
\text { meetings at } \\
\text { the } \\
\text { company }\end{array}$ & $\begin{array}{l}\text { Regular } \\
\text { work } \\
\text { meetings at } \\
\text { home }\end{array}$ & $\begin{array}{l}\text { Regular } \\
\text { work } \\
\text { meetings } \\
\text { held in an } \\
\text { other, } \\
\text { external } \\
\text { venue }\end{array}$ & Other \\
\hline \multirow{4}{*}{$\begin{array}{l}\text { „What is the main decision } \\
\text { making body in your firm on } \\
\text { operative issues, that is } \\
\text { issues having a weekly, } \\
\text { monthly or within a year } \\
\text { effect?" (in \%) }\end{array}$} & Whole sample & 46.69 & 39.67 & 3.31 & 10.33 \\
\hline & 1st generational & 41 & 45.3 & 3.3 & 10.4 \\
\hline & 2nd generational & 60.3 & 24.1 & 3.4 & 12.2 \\
\hline & 3rd generational & 100 & 0 & 0 & 0 \\
\hline
\end{tabular}

Notes: There's only one item of third generational firm in the subsample. Percentage values in each row (generation) add up to 100 .

\begin{tabular}{|c|c|c|c|c|c|c|}
\hline $\begin{array}{c}\text { Survey } \\
\text { question }\end{array}$ & Population & $\begin{array}{c}\text { Weekly more } \\
\text { occasion }\end{array}$ & $\begin{array}{c}\text { Once a } \\
\text { week }\end{array}$ & $\begin{array}{c}\text { In every } \\
\text { second } \\
\text { week }\end{array}$ & Monthly & $\begin{array}{c}\text { In every } \\
\text { second } \\
\text { month }\end{array}$ \\
\hline \multirow{2}{*}{$\begin{array}{c}\text { Frequency } \\
\text { of these } \\
\text { meetings?" } \\
\text { (in \%) }\end{array}$} & Whole sample & 39.21 & 24.23 & 6.17 & 19.82 & 10.57 \\
\cline { 2 - 7 } & 1 st generational & 42.3 & 23 & 4.7 & 20 & 10 \\
\cline { 2 - 7 } & $\begin{array}{c}\text { 2nd } \\
\text { generational }\end{array}$ & 30.9 & 27.2 & 10.9 & 18.18 & 12.82 \\
\hline 3rd & generational & NA & NA & NA & NA & NA \\
\hline
\end{tabular}


1. Top Management Team - cont.

\begin{tabular}{|c|c|c|c|c|c|c|c|c|}
\hline $\begin{array}{c}\text { Survey } \\
\text { question }\end{array}$ & Population & Average & Std. Dev. & Minimum & Q1 & Median & Q3 & $\begin{array}{c}\text { Maxim } \\
\text { um }\end{array}$ \\
\hline \multirow{4}{*}{$\begin{array}{c}\text { „How } \\
\text { many } \\
\text { people } \\
\text { participat } \\
\text { e in these } \\
\text { meetings } \\
\text { in } \\
\text { general?” }\end{array}$} & $\begin{array}{l}\text { Whole } \\
\text { sample }\end{array}$ & 3.38 & 1.85 & 1 & 2 & 3 & 4 & 16 \\
\hline & $\begin{array}{c}1 \mathrm{st} \\
\text { generational }\end{array}$ & 3.23 & 1.73 & 1 & 2 & 3 & 4 & 15 \\
\hline & $\begin{array}{c}2 \text { nd } \\
\text { generational }\end{array}$ & 3.64 & 1.42 & 1 & 3 & 3 & 4 & 10 \\
\hline & $\begin{array}{c}\text { 3rd } \\
\text { generational }\end{array}$ & 2.5 & NA & 2.5 & 2.5 & 2.5 & 2.5 & 2.5 \\
\hline \multirow{4}{*}{$\begin{array}{c}\text { „Ratio of } \\
\text { family } \\
\text { members } \\
\text { in these } \\
\text { meetings? } \\
\text { „ }\end{array}$} & $\begin{array}{l}\text { Whole } \\
\text { sample }\end{array}$ & 0.82 & 0.28 & 0 & 0.67 & 1 & 1 & 1 \\
\hline & $\begin{array}{c}1 \mathrm{st} \\
\text { generational }\end{array}$ & 0.82 & 0.28 & 0 & 0.67 & 1 & 1 & 1 \\
\hline & $\begin{array}{c}2 \mathrm{nd} \\
\text { generational }\end{array}$ & 0.84 & 0.28 & 0 & 0.75 & 1 & 1 & 1 \\
\hline & $\begin{array}{c}\text { 3rd } \\
\text { generational }\end{array}$ & 0.8 & NA & 0.8 & 0.8 & 0.8 & 0.8 & 0.8 \\
\hline
\end{tabular}

\section{Board of Directors}

\begin{tabular}{|c|c|c|c|c|c|}
\hline \multicolumn{1}{|c|}{ Survey question } & Population & $\begin{array}{c}\text { Identical } \\
\text { with the } \\
\text { previous } \\
\text { (leadership } \\
\text { team) }\end{array}$ & $\begin{array}{c}\text { Regular } \\
\text { strategical } \\
\text { meetings at } \\
\text { the } \\
\text { company }\end{array}$ & $\begin{array}{c}\text { Regular } \\
\text { strategical } \\
\text { meetings at } \\
\text { home }\end{array}$ & $\begin{array}{c}\text { Regular } \\
\text { strategical } \\
\text { meetings } \\
\text { held in an } \\
\text { external } \\
\text { venue }\end{array}$ \\
\hline $\begin{array}{l}\text { „What is the main } \\
\text { decision making body in } \\
\text { your firm on strategical } \\
\text { issues, that is issues } \\
\text { having an effect beyond } \\
\text { one year period?" (in \%) }\end{array}$ & Whole sample & 23.33 & 36.25 & 36.25 & 4.17 \\
\cline { 2 - 6 } & 2nt generational & 25.1 & 29 & 41.3 & 4.6 \\
\cline { 2 - 6 } & 3rd generational & 0 & 100 & 22.4 & 3.54 \\
\hline
\end{tabular}

\begin{tabular}{|c|l|r|r|r|r|}
\hline \multirow{2}{*}{ Survey question } & Population & Annualy & $\begin{array}{c}\text { Twice a } \\
\text { year }\end{array}$ & $\begin{array}{c}\text { In every } \\
\text { 2-3 } \\
\text { months }\end{array}$ & Monthly \\
\hline \multirow{3}{*}{ „Frequency of these meetings?" (in \%) } & Whole sample & 9.62 & 11.54 & 17.31 & 61.54 \\
\cline { 2 - 6 } & 1st generational & 9.04 & 11.36 & 13.6 & 66 \\
\cline { 2 - 6 } & 2nd generational & 12.5 & 12.5 & 37.5 & 37.5 \\
\cline { 2 - 6 } & 3rd generational & NA & NA & NA & NA \\
\hline
\end{tabular}


2. Board of Directors - cont.

\begin{tabular}{|c|c|c|c|c|c|c|c|c|}
\hline Survey question & Population & Average & Std. Dev. & Minimum & Q1 & Median & Q3 & Maximum \\
\hline \multirow{2}{*}{$\begin{array}{c}\text { „How many } \\
\text { people } \\
\text { participate in } \\
\text { these meetings } \\
\text { in general?" }\end{array}$} & Whole sample & 3.19 & 1.9 & 0 & 2 & 3 & 4 & 12 \\
\cline { 2 - 9 } & 2nt generational & 3.25 & 1.97 & 2 & 2 & 3 & 4 & 12 \\
\hline & 3rd generational & NA & NA & NA & NA & NA & NA & NA \\
\hline \multirow{2}{*}{$\begin{array}{c}\text { „Ratio of } \\
\text { family } \\
\text { members in } \\
\text { these } \\
\text { meetings?" }\end{array}$} & Whole sample & 0.85 & 0.3 & 0 & 1 & 1 & 1 & 1 \\
\cline { 2 - 9 } & 2nt generational & 0.83 & 0.32 & 0 & 0.92 & 1 & 1 & 1 \\
\cline { 2 - 9 } & 3rd generational & NA & NA & NA & NA & NA & NA & NA \\
\hline
\end{tabular}

\section{Shareholders' meeting}

\begin{tabular}{|l|c|c|c|c|c|c|}
\hline \multirow{2}{*}{ Survey question } & Population & $\begin{array}{c}\text { Identical } \\
\text { to the } \\
\text { Strategical } \\
\text { meetings }\end{array}$ & $\begin{array}{c}\text { Shareholder's } \\
\text { meetings } \\
\text { held at the } \\
\text { company }\end{array}$ & $\begin{array}{c}\text { Meetings } \\
\text { held at } \\
\text { home }\end{array}$ & $\begin{array}{c}\text { Shareholder's } \\
\text { meetings } \\
\text { held in other, } \\
\text { external } \\
\text { venue }\end{array}$ & Other \\
\hline \multirow{2}{*}{$\begin{array}{l}\text { "What is the main } \\
\text { decision making } \\
\text { body in your firm on } \\
\text { ownership issues?" } \\
\text { (in \%) }\end{array}$} & Whole sample & 9.14 & 34.86 & 45.14 & 4.57 & 6.29 \\
\cline { 2 - 7 } & 1st generational & 8,4 & 30,7 & 50,77 & 4,03 & 6,1 \\
\cline { 2 - 8 } & 2nd generational & 11.6 & 44.1 & 30.2 & 7.05 & 7.05 \\
\hline
\end{tabular}

\section{Family Council}

\begin{tabular}{|l|c|c|c|c|c|c|}
\hline \multicolumn{1}{|c|}{ Survey question } & Population & $\begin{array}{c}\text { Identical } \\
\text { to the } \\
\text { Strategical } \\
\text { meetings }\end{array}$ & $\begin{array}{c}\text { Meetings } \\
\text { held at } \\
\text { the } \\
\text { company }\end{array}$ & $\begin{array}{c}\text { Meetings } \\
\text { held at } \\
\text { home }\end{array}$ & $\begin{array}{c}\text { Meetings } \\
\text { held in } \\
\text { other, } \\
\text { external } \\
\text { venue }\end{array}$ & Other \\
\hline \multirow{2}{*}{$\begin{array}{l}\text { "What is the main } \\
\text { forum of problems and } \\
\text { issues on the } \\
\text { relationship of the } \\
\text { family and the firm?" } \\
\text { (in \%) }\end{array}$} & Whole sample & 8.28 & 36.69 & 47.34 & 4.14 & 3.55 \\
\cline { 2 - 8 } & 1st generational & 8,1 & 32,5 & 53,65 & 3,2 & 2,55 \\
\cline { 2 - 8 } & 2nd generational & 9 & 45,4 & 31,81 & 6,99 & 6,8 \\
\hline
\end{tabular}

\subsubsection{Descriptive statistics}

Formulation of the main questions and main results are shown in Table 3. Majority of the businesses (46.69\%) held the Top Management Team's meeting at 
the company, but a considerable part (39.67\%) has this gathering at home. As far as the Board of Directors are concerned, almost quarter of them do not distinguish it from the Top Management Team's meetings. From those who make this differentiation, the same proportion choose the company and the home as a venue (36.25-36.25\%).

Number of participants in Top Management Teams is larger than in Boar of Directors' meetings, but ratio of family members is larger in the latter ones, which underlies that the function of leading can also be exercised by non-family members, but function of control is let out from family's hands to a lesser extent.

Although Shareholder's Meeting is a formal, separated and legally regulated event, larger part of them (45\%) reported that they hold this body at home, and $34.86 \%$ of them at the company. This may reflect that beyond the organization of a legally required annual meeting, Hungarian family businesses rather practice the ownership function also at home.

Greater part of them (91.72\%) has a meetings of family and business relationship separated from other governance mechanisms, $47.34 \%$ at home, and $36.69 \%$ at the company.

According to the results in Table 3, there are differences in data between the first and second generational family businesses. Both Top Management Team's meetings and Board of Directors' meetings started to be held at the company instead of home to a significantly higher extent, and separated more from each other. Their frequency also drop off: Top Management Team's meeting is rather held more than once a week at first generational firms, while at second generational firms, the once a week rate are almost as large as the more than once a week option. Frequency of Board of Directors' meetings is rather monthly at first generation, while till the second generation it lessens to inbetween monthly and 2-3 monthly rates. The same tendency of increasing importance of the company as a venue can be observed in the case of the Shareholder's Meeting. Even majority of Family Councils starts to be organized more at the company at the second generational firms than at home.

Concluding the above described preference for holding meetings of business governance mechanisms at home and the reported overlap of these meetings, I can hypothesize that at this stage of development, when majority of Hungarian family 
businesses are first or second generational, the function of leading and controlling of the company's top management is partially taken over by the Family Council. Although this hypothesis assumes that meetings held at home can be directly linked to the operation and functional fulfilment of the Council - which can not be proved from the data because the research itself has a different and wider scope. But intuitively, it can be argued that these small and medium firms do not distinguish between these meetings, they assign separate time for discussing family and business matters on their own at home, and during these occasions both operative and strategic business issues may also emerge ${ }^{5}$.

Concluding the data on generational differences, I can state that as family businesses grow into second generational, the governance mechanisms become more differentiated from each other, and separated from home: companies are more matured and professionalized.

Moreover, at the operative meetings, both the number of involved family members, and the ratio of family members increasing after the turn from first to second generational firm. At strategical meetings however, although the number of involved family members declines, ratio of family members expands. This is an empirical result that can more elaborate the above described general grow patterns of small and medium Hungarian family businesses: as they develop in time, top management function is extended and fulfilled by more family members, while control function is held within the family to a larger degree.

\subsubsection{Development of governance mechanisms}

The governance classification based on the three-circle model may suggest an ideal governance structure being not exposed to temporal changes and development. However, in their inceptional phase, family businesses' governance structure is less differentiated, while at a matured phase their governance mechanisms can also be more elaborated than that.

\footnotetext{
5 Other previous targeted research fully proved this hypotheses among Italian SME firms (Gnan et al. 2015).
} 
As families grow, family members mature and number of family members increases. This process also automatically implies change in ownership configuration and ownership governance. In parallel with this process, companies as business organization also go through different developmental stages. Gersick and his colleagues devoted their seminal model (Gersick et al. 1997) to describe this natural, but compound triadic developmental process. Some other authors apply the word of ,complexity” for labeling this development in one of the subsystems (Suess 2014).

From the perspective of governance structure, another possible option to describe this development is to illustrate it by functional terms (Koeberle-Scmied, Caspersz 2013). At the establishment of the company (which usually is an entrepreneurship, not a family business) every main function of leading, controlling, owning and nurturing the family-business relationship is fulfilled by one man, the entrepreneur himself/herself (or by a small circle of family members who launched the business together). Later on, as „complexity” of both family and business systems grows, a systemic need may emerge for the manifestation of a separate governance mechanism as a tool that can separately satisfy a specific function - thus firstly the top management team, then Board of Directors, and Family Council is firstly informally, and then formally will be established. The further development of the family business system over time will surely lead to the design and implementation of a more intricate and elaborate governance structure. The development of governance structures are well-known, but less researched area of family business governance literature (Uhlaner 2007; Gersick-Feliu 2014).

Although the elaboration of this topic lies beyond the scope of this paper, I would like to contribute to the joint efforts by showing how tangible this development is when one concentrates on the governance functions instead of the formal existence of the governance mechanisms or tools.

For constructing Figure 1-3, I assumed that as part of the temporal development, level of complexity and professionalization of the company increase, the governance mechanisms (asked about in the questionnaire) become separated from each other more clearly - the significance of home as a meeting venue will decrease and meetings of the inspected governance mechanisms will tend to be held rather in the 
company site. For evaluating the level of separation of these mechanisms, I calculated the number of separate mechanisms at the case of each entry in the subsample (its value can set to the minimum of 0 , and the maximum of 4). I measured complexity/professionalization by the proxy variables of number of employees, annual revenue, and also age of the firm. Based on the above assumption, the more matured/professionalized the company is, the higher the number of the separated mechanisms which are held in the company.

Figure 1-3 shows the results. Although I found clear connection between measured variables, since the plots (observations) may set only five values, and may also overlap each other, the picture of the plots themselves alone can not reflect back the strengths of the relationship between the variables. That is why I decided on fitting functions on the data with applying the LOESS smoothing method (Cleveland 1979). As one can see on Figure 1-3, all functions are almost monotonously growing, there are stagnating sections at the beginning in case of the revenue and the number of employees. Interestingly, the latter function is around stagnating until the firms reach the value of 10 employees, and starts to increase only after the headcount of 10 employees.

Figure 1. Relationship between number of governance mechanisms whose meetings are held at the company and the revenue of the company

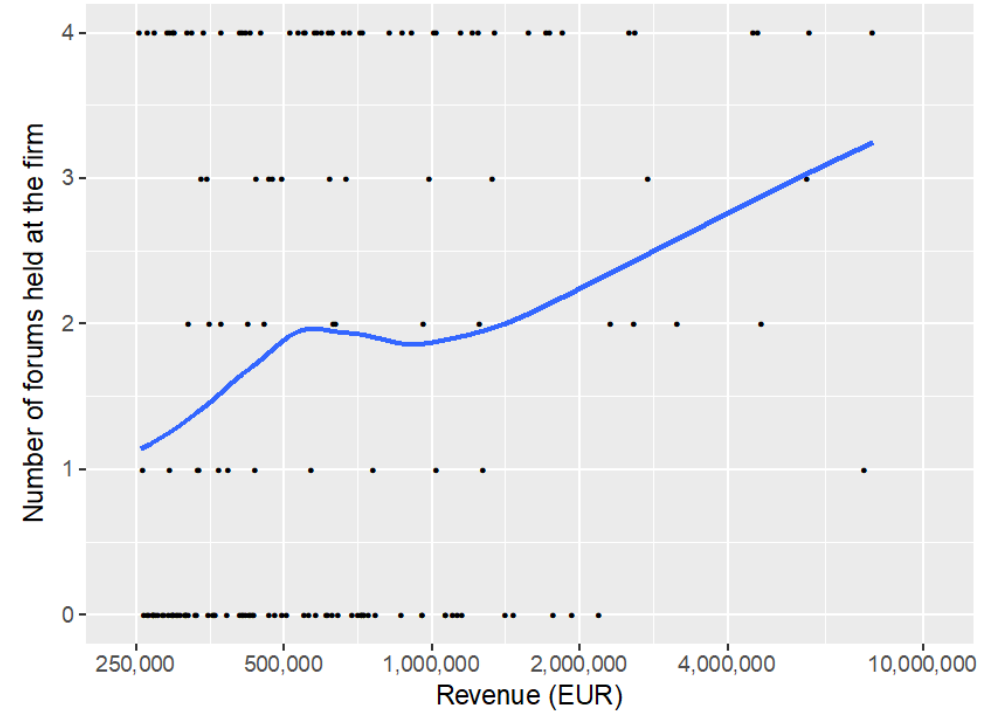


Figure 2. Relationship between number of governance mechanisms whose meetings are held at the company and the age of the company

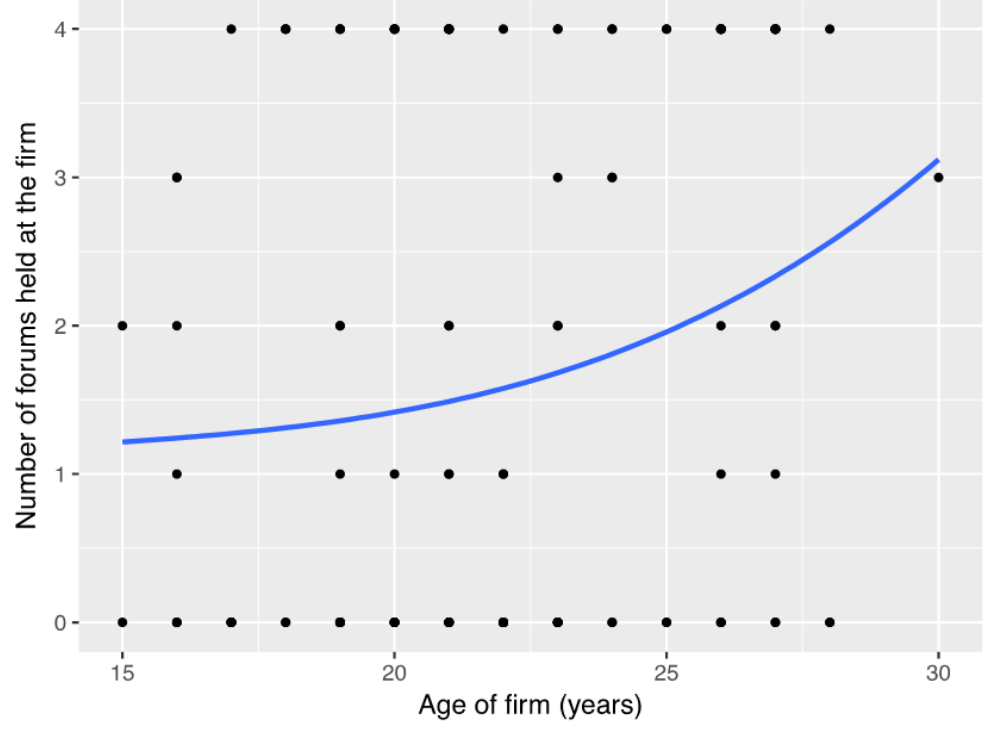

Figure 3. Relationship between number of governance mechanisms whose meetings are held at the company and the age of the company

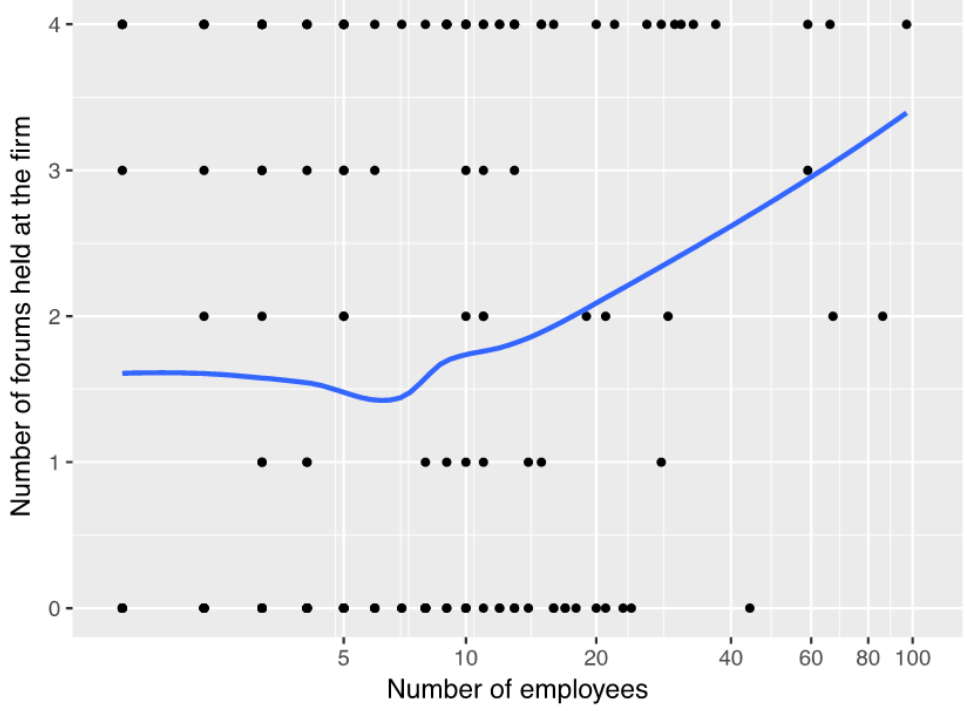




\subsubsection{Topics discussed in the Top Management Team}

Survey questionnaire also asked family businesses about the frequency of discussing specific professional topics in the top management team. Set of the topics covers all of the functional issues necessary for the management of a business organization.

Table 4. Frequency of discussion of topics in the Top Management Team

\begin{tabular}{|l|c|c|c|c|c|}
\hline \multicolumn{1}{|c|}{ Topics } & Never & Once a year & Quarterly & Monthly & Weekly \\
\hline Turnover & 14 & 21 & 49 & 98 & 56 \\
\hline Strategy and goals & 12 & 41 & 71 & 60 & 55 \\
\hline Quality of goods and services & 18 & 12 & 26 & 63 & 117 \\
\hline $\begin{array}{l}\text { Market position, corporate competences } \\
\text { and resources }\end{array}$ & 24 & 33 & 61 & 73 & 53 \\
\hline Cash position & 23 & 15 & 34 & 68 & 99 \\
\hline Directions of market growth & 17 & 34 & 81 & 54 & 51 \\
\hline Human resources management & 36 & 48 & 53 & 52 & 49 \\
\hline Financial planning and position & 15 & 34 & 55 & 74 & 60 \\
\hline Organizational structure & 54 & 79 & 38 & 42 & 22 \\
\hline Workplace atmosphere & 49 & 18 & 36 & 62 & 74 \\
\hline Branding & 107 & 64 & 25 & 29 & 10 \\
\hline $\begin{array}{l}\text { Technological problems during } \\
\text { production }\end{array}$ & 45 & 17 & 32 & 55 & 85 \\
\hline
\end{tabular}

Their natural and high concern for the turnover, quality of goods and services, implementations of strategy and corresponding goals, and the directions of market growth reflects that they are operating as a business organization - their operation is functionally adequate.

Moreover, from the frequency of discussion of certain topics one can also formulate assumptions regarding their level of professionalization (Dekker et al. 2015). From this regard, the picture is ambiguous. The relatively high frequency of financial planning and cash management shows that they gained momentum in the 
professionalization process. However, the relatively low level of human resource management signals important deficiencies in their operation.

\subsubsection{Operation of Family Councils}

With the aim of exploring the operation of Family Councils at the inspected firms more profoundly, the survey puts three questions at the end of the governance section of the questionnaire which target at the internal functioning of this governance mechanism at the Hungarian family businesses. The first questioned about the frequency of discussion of all possible topics in a Family Council. The second question investigated whether family and the firm have a formal or informal regulation on all of the possible regulatory issues. The third question directly asked about the possible existence of the Family Constitution. Table 5-7 shows the results considering these questions.

\section{Table 5. Distribution of frequencies of issues on family-firm relationship}

Survey question: „How often do you discuss the following topics in the meetings on the relationship of family and the firm?"

\begin{tabular}{|l|c|c|c|c|c|c|}
\hline \multicolumn{1}{|c|}{ Topic } & Never & Annually & Quarterly & Monthly & Weekly & No answer \\
\hline $\begin{array}{l}\text { a) Relationship between family and } \\
\text { the top management of the company? }\end{array}$ & 41.13 & 17 & 8.06 & 12.9 & 19.35 & 1.56 \\
\hline $\begin{array}{l}\text { b) Creation of family unity regarding } \\
\text { the ownership of the company }\end{array}$ & 50.8 & 21.37 & 8.06 & 6.85 & 8.87 & 4.05 \\
\hline c) Succession & 56.85 & 25.8 & 6.04 & 5.64 & 4.03 & 1.64 \\
\hline d) Issues of ownership & 58.63 & 25.3 & 5.62 & 5.22 & 2.81 & 2.42 \\
\hline $\begin{array}{l}\text { e) Education and information of } \\
\text { family members in business matters }\end{array}$ & 27.3 & 15.5 & 14.7 & 17.6 & 22.4 & 2.5 \\
\hline
\end{tabular}

Source: author's own elaboration based on Suáre, Santana-Martin (2004).

Regarding the frequency of possible topics that belong to the Family Council, one can identify two groups of topics. The first group contains the first and the fifth topic, where the proportion of the answers "We never discuss such topic" is relatively smaller than at other topics, while the proportion of the answers „We discuss such topic in every month/week." is relatively higher. These topics are linked to the relationship of the family and company management and to informing 
and educating family members in business issues - they relate to the continuous connecting role of the council bridging family and company.

The second group incorporates the third and the fourth topics. Interviewed families predominantly chose the answer of „We never discuss such topic”, ensued by the answer „We discuss such topic once a year”. These topics can be linked to long-term issues of succession and questions and challenges of ownership.

Family Councils have a persistent function of linking family and business and also a long-term function regarding the planning of the maintenance of family control over the company. Based on the data, Hungarian Family Councils perform relatively better in the previous one, whereas they are hardly able to fulfill the latter function.

The second topic („Formation of family unity regarding the ownership”) proved to be a hybrid one, showing resemblance to both groups regarding the internal distribution of the answers. This may suggest that families do take care of family unity, but concentrating on the actual problems, instead of thinking about the possible future challenges inherently built in into the family business system.

Table 6. Distribution of frequencies of specific family rules Survey question: „What rules do you have from the following possible rules in your family?" (in \%)

\begin{tabular}{|l|c|c|}
\hline \multicolumn{1}{|c|}{ Rules } & We don't have & We have \\
\hline $\begin{array}{l}\text { a) Rules on decision making an conflict resolution on the relationship } \\
\text { between firm and family }\end{array}$ & 85.25 & 14.75 \\
\hline b) Rules of employment of family members at the family firm & 77.91 & 22.09 \\
\hline $\begin{array}{l}\text { c) Rules for family members on participating in the strategical } \\
\text { decision-making of the family firm }\end{array}$ & 78.08 & 21.92 \\
\hline d) Rules on handling and managing ownership rights and liabilities & 72 & 28 \\
\hline e) Rules on succession & 90.4 & 9.6 \\
\hline $\begin{array}{l}\text { f) Rules on patronage, supporting philanthropic or community } \\
\text { activities }\end{array}$ & 88.16 & 11.84 \\
\hline $\begin{array}{l}\text { g) Rules on how family members can be supported in launching a } \\
\text { new business venture }\end{array}$ & 92.82 & 7.18 \\
\hline
\end{tabular}

Source: author's own elaboration based on Carlock, Ward (2001).

Further data on the existence of rules (Table 6) also confirms the findings on the performance characteristics of the Hungarian Family Councils. 
The last two rules are rather applicable at more matured family business systems, usually at higher generational level, where the complexity of both the family and the company is higher which generates new kinds of needs and expectations regarding the Family Council. It is no wonder that large part of Hungarian family business systems has not developed any regulations on these issues - they received the lowest proportion of „yes" answers from the family businesses.

The rules (questions) b)-e) represent the core functioning of a Family Council. The existence of rules has the highest proportion at these questions with one clear exception of the rules on succession. It may reflect that the operation of the Family Councils has been launched in general, they fulfill their function in shorter-term challenges, but - again - are hardly able to face long-term demands of the development of the whole family business system.

\section{Table 7. Presence of Family Constitution}

Survey question: „Do you have Family Constitution?” (in \%)

\begin{tabular}{|c|c|}
\hline Yes & No \\
\hline 2.82 & 97.18 \\
\hline
\end{tabular}

Questions about family rules and Family Constitution are interrelated in the sense that those classic rules were questioned that are usually included in a constitution in a formal, written way. Interestingly, large majority of the firms stated that they do not have any Family Constitution whereas not their greater part, but many of them also indicated that they do have rules for these issues (although not in a written form) (see Table 7).

This may suggest that the institution of Family Constitution is less known among Hungarian family businesses, and also that perhaps they simply do not need one at their stage of development: answers for this question were received from first and second generational, small and medium-sized firms. 


\subsubsection{Family businesses with under and above the average economic performance}

I would like to close the description of the main findings of the research and analysis of the governance practices at Hungarian family businesses by comparing family businesses with under and above the average economic performance. Three reasons explain to put an emphasis on such comparision. Firstly, the nature of the survey is explorative and descriptive, and not theory-led (although the exploration is based on accepted, well-tried models). This comparision would reflect the datas from a new perspective and may thus deliver new understanding of the results. Secondly, differences gained from the comparision are in accordance with the practical suggestions of the academic literature based on research results. Thirdly, economic performance data of a given business from the database is an aggregated variable from three economic outcome questions, which distribution is almost symmetric, unimodal, thus its average equals its median value. Henceforth any splitting along either the average or the median as possible splitting points delivers the same result: it creates two groups with the same number of elements.

At Hungarian family businesses having above the average economic performance, the borders of the family business system are more flexible: both the average number of family members involved into the operation of the firm and the ratio of non-family members (presumably professionals) involved into the Top Management Team are higher. Operation of the Family Council is separated to a larger extent from the decision making of the Top Management Team and from strategic decision making. Regarding the topics discussed in Family Councils, educating and informing family members on business issues are more frequent than family businesses having under the average economic performance. Relationship of family and business are more regulated.

Likelihood of having a succession plan is higher at family businesses with above the average economic performance. In this group, present incumbents also plan to work still for the company after the formal transition of succession, but the ratio of incumbents who want to be involved both into the operative and the strategic decision making is smaller than at the case of the other group. When ranking the 
challenges of succession, they are more apt to play an active role in the process than the passive attitude of the other group's members. Family firms from the group of above the average economic performance value their firms emotionally higher.

\section{Conclusion}

Based on the results from the survey on Hungarian family business profile at the turn of 2017/18 one can conclude that large majority (around 91\%) of these firms are small-sized and medium-sized (only less than $8 \%$ ) and large-sized (bit more than $1 \%)$ to a less fewer extent.

Microenterprises can certainly develop into small businesses - involvement of more family members from the next generation by the founder and his/her spouse into the operative work means the key for this process. This is clearly the best outcome both from the perspective of the family and the company.

They are less able however for the next shift: hiring external, non-family professionals into the top management. It would be especially crucial for small businesses in the process of becoming a medium-sized business.

The developmental pattern of their governance practices refers to their increasing level of professionalization: the governance mechanisms of the business and ownership become more separated from each other and also from the family. The relationship between the firm and the family turns into a more regulated form.

On the other hand, the fact that HR-related topics are relatively less significant reflects back the fractual nature of their professionalization. Their Family Councils may fulfil the persistent function of bridging family and company, but are less able to satisfy their other important, long-term function regarding the planning of the maintenance of family control over the company.

My study is subject to more limitations. Firstly, as a general note, the original research was exploratory in nature, the results only deliver a bird's view of the field. The more focused the analysis was, the more grained the picture I got from the data became. The results are representative for the whole population only at the case of the first questionnaire. With the second questionnaire, I was rather able to explore 
tendencies based on which I am able to conduct more targeted research in the future. Secondly, the analysis is based on the scholarship of the field, which is not countryspecific - detailed analysis of the local, Hungarian institutional factors and legal context was not included (with the exception of the entrepreneurial family history). The empirical results can be assessed and compared with other research results, but one should always keep in mind this important limitation of the research.

\section{References}

Anderson R.C., Reeb D.M. (2004), Board composition: balancing family influence in S\&P 500 firms, „Administrative Science Quarterly”, vol. 49 no. 2, pp. 209-237.

Bammens Y., Voordeckers W., van Gils A. (2011), Boards of directors in family businesses. A literature review and research agenda, „International Journal of Management Reviews”, vol. 13 no. 2, pp. 134-152.

Berrone P., Cruz C., Gómez-Mejía L.R. (2012), Socioemotional wealth in family businesses theoretical dimensions, assessment approaches, and agenda for future research, „Family Business Review”, vol. 25 no. 3, pp. 258-279.

Carlock R.S., Ward J.L. (2001), Strategic planning for the family business. Parallel planning to unify the family and the business, Palgrave MacMillan, Basingstoke.

Carney M., van Essen M., Gedajlovic E.R., Heugens P.P.M.A.R. (2013), What do we know about private family businesses? A meta-analytical review, „Entrepreneurship Theory and Practice”, vol. 39 no. 3, pp. 1-32.

Chrisman J.J., Chua J.H., Litz R.A. (2004), Comparing the agency costs of family and non-family businesses. Conceptual issues and exploratory evidence, „Entrepreneurship Theory and Practice”, vol. 28 no. 4 , pp. 335-354.

Chua J., Chrisman J., Bergiel E. (2009), An agency theoretical analysis of the professionalized family business, „Entrepreneurship Theory and Practice”, vol. 33 no. 2, pp. 355-372.

Cleveland W.S. (1979), Robust locally weighted regression and smoothing scatterplots, „Journal of the American Statistical Association", vol. 74 no. 368, pp. 829-836.

Dana L.P., Ramadani V. (2015), Context and uniqueness of transition economies, in: Family businesses in transition economies - management, succession and internationalization, Dana L.P., Ramadani V. (eds.), Springer International Publishing, Cham.

Dawson A., Parada M.J. (2019), Corporate governance in family businesses across generations. Exploring intergenerational issues, in: The Palgrave Handbook of heterogeneity among family firms, Memili E., Dibrell C. (eds.), Palgrave Macmillan, Basingstoke. 
Debicki B.J., Kellermanns F.W., Chrisman J.J., Pearson A.W., Spencer B.A. (2016), Development of a socioemotional wealth importance (SEWI) scale for family business research, „Journal of Family Business Strategy", vol. 7 no. 1, pp. 47-57.

Dekker J., Lybaert N., Steijvers T., Depaire B. (2015), The effect of family business professionalization as a multidimensional construct on firm performance, „Journal of Small Business Management”, vol. 53 no. 2 , pp. 516-538.

Dinh T.Q., Calabrò A. (2019), Asian family businesses through corporate governance and institutions. A systematic review of the literature and agenda for future research, "International Journal of Management Reviews", vol. 21 no. 1, pp. 50-75.

Forgy E.W. (1965), Cluster analysis of multivariate data. Efficiency versus interpretability of classifications, „Biometrics”, vol. 21 no. 3, pp. 768-769.

Fraley C., Raftery A.E. (2002), Model-based clustering, discriminant analysis and density estimation, „Journal of the American Statistical Association”, vol. 97 no. 458, pp. 611-631.

Gersick K.E., Davis J.A., McCollom Hampton M., Lansberg I. (1997), Generation to generation. Life cycles of the family business, Harvard Business School Press, Boston.

Gersick K.E., Feliu N. (2014), Governing the family enterprise. Practices, performance and research, in: The Sage Handbook of family business, Melin L., Nordqvist M., Sharma P. (eds.), Sage Publications, Thousand Oaks, CA.

Goel S., Jussila I., Ikäheimonen T. (2014), Governance in family businesses. A review and research agenda, in: The Sage Handbook of family business, Melin L., Nordqvist M., Sharma P. (eds.), Sage Publications, Thousand Oaks, CA.

Gómez-Mejía L.R., Cruz C., Berrone P., De Castro J. (2011), The bind that ties. Socioemotional wealth preservation in family businesses, „The Academy of Management Annals”, vol. 5 no. 1, pp. 653-707.

Gómez-Mejía L.R., Nunez-Nickel M., Gutierrez I. (2001), The role of family ties in agency contracts, „Academy of Management Journal”, vol. 44 no. 1, pp. 81-95.

Gnan L., Montemerlo D., Huse M. (2015), Governance systems in family SMEs. The substitution effects between Family Councils and corporate governance mechanisms, ,Journal of Small Business Management", vol. 53 no. 2, pp. 355-381.

Hauck J., Suess-Reyes J., Beck S., Prügl R., Frank H. (2016), Measuring socioemotional wealth in family-owned and -managed firms. A validation and short form of the FIBER Scale, ,Journal of Family Business Strategy", vol. 7, pp. 133-148.

Holt D., Pearson A.W., Carr J.C., Barnett T. (2017), Family business(s) outcomes model. Structuring financial and nonfinancial outcomes across the family and firm, „Family Business Review”, vol. 30 no. 2, pp. 182-202.

Huang Z. (1998), Extensions to the k-means algorithm for clustering large data sets with categorical variables, „Data Mining and Knowledge Discovery”, vol. 2 no. 3, pp. 283-304. 


\section{GOVERNANCE IN HUNGARIAN FAMILY BUSINESSES}

Huse M. (2009), The value creating board. Corporate governance and organizational behaviour, Routledge, Abingdon.

Jaskiewicz P., Gibb Dyer W. (2017), Addressing the elephant in the room. Disentangling family heterogeneity to advance family business research, „Family Business Review”, vol. 30 no. 2, pp. 111118.

Kodinariya T., Dan Makwana P.R. (2013), Review on determining of cluster in k-means clustering, „International Journal of Advance Research in Computer Science and Management Studies”, vol. 1 no. 6, pp. 90-95.

Koeberle-Schmied A., Caspersz D. (2013), Family governance bodies. A conceptual typology, in: Handbook of research on family business, Smyrnios K.X., Poutziouris P.Z. (eds.), Edward Elgar Publishing, Cheltenham.

Koeberle-Schmid A., Kenyon-Rouvinez D., Poza E.J. (2014), Governance in family enterprises maximizing economic \& emotional success, Palgrave Macmillan, Basingstoke.

Le Breton-Miller I., Miller D. (2009), Agency vs. stewardship in public family businesses. A social embeddedness reconciliation, „Entrepreneurship Theory and Practice”, vol. 33 no. 6, pp. 1169-1191.

Ling Y., Kellermanns F. (2010), The effects of family business specific sources of TMT diversity. The moderating role of information exchange frequency, „Journal of Management Studies”, vol. 47 no. 2, pp. 322-344.

Lubatkin M., Lane P.J., Collin S., Very P. (2007a), An embeddedness framing of governance and opportunism. Towards a cross-nationally accommodating theory of agency, ,Journal of Organizational Behavior", vol. 28, pp. 43-58.

Lubatkin M.H., Ling Y., Schulze W.S. (2007b), An organizational justice-based view of self-control and agency costs in family businesses, „Journal of Management Studies”, vol. 44 no. 6, pp. 955-971.

Memili E. (2011), Control-enhancing corporate governance mechanisms. Family versus nonfamily publicly traded firms, doctoral dissertation, Mississippi State University.

Miller D., Le Breton-Miller I. (2006), Family governance and firm performance. Agency, stewardship, and capabilities, „Family Business Review”, vol. 19 no. 1, pp. 73-87.

Miller D., Le Breton-Miller I. (2011), Governance, social identity, and entrepreneurial orientation in closely held public companies, „Entrepreneurship Theory and Practice”, vol. 35 no. 5, pp. 1051-1076.

Nordqvist M., Sharma P., Chirico F. (2014), Family business heterogeneity and governance. A configuration approach, ,Journal of Small Business Management”, vol. 52 no. 2, pp. 192-209.

North D.C. (1990), Institutions, institutional change and business performance, Cambridge University Press, Cambridge.

Pindado J., Requejo I. (2015), Family business performance from governance perspective. A review of empirical research, „International Journal of Management Reviews”, vol. 17 no. 3, pp. 279-311. 
Siebels J-F., zu Knyphausen-Aufseß D. (2012), A review of theory in family business research. The implications for corporate governance, ,International Journal of Management Reviews”, vol. 14 no. 3 , pp. 280-304.

Suáre K.C., Santana-Martín D.J. (2004), Governance in Spanish family business, „International Journal of Entrepreneurial Behavior \& Research", vol. 10 no. 1/2, pp. 141-163.

Schulze W.S., Lubatkin M.H., Dino R.N., Buchholtz A.K. (2001), Agency relationship in family businesses. Theory and evidence, „Organization Science”, vol. 12 no. 2, pp. 99-116.

Sharma P. (2004), An overview of the field of family business studies. Current status and directions for the future, „Family Business Review”, vol. 17 no. 1, pp. 1-36.

Sieger P., Zellweger T., Aquino K. (2013), Turning agents into psychological principals. Aligning interests of nonowners through psychological ownership, „Journal of Management Studies”, vol. 50 no. 3, pp. 361-388.

Stanley L., Kellermanns F.W., Zellweger T. (2017), Latent profile analysis. Understanding family business profiles, „Family Business Review”, vol. 30 no. 1, pp. 84-102.

Suess, J. (2014), Family governance. Literature review and the development of a conceptual model, „Journal of Family Business Strategy”, vol. 5 no. 2, pp. 138-155.

Thorndike R.L. (1953), Who belongs in the family?, „Psychometrika”, vol. 18 no. 4, pp. 267-276.

Uhlaner L., Wright M., Huse M. (2007), Private firms and corporate governance. An integrated economic and management perspective, „Small Business Economics”, vol. 29 no. 3, pp. 225-241.

Van Essen M., Carney M., Gedajlovic E.R., Heugens P.P.M.A.R. (2015), How does family control influence firm strategy and performance? A meta-analysis of US publicly listed firms, „Corporate Governance. An International Review", vol. 23 no. 1, pp. 3-24.

Zellweger T., Nason R., Nordqvist M., Brush C.G. (2013), Why do family businesses strive for nonfinancial goals? An organizational identity perspective, „Entrepreneurship Theory and Practice”, vol. 37 no. 2 , pp. $229-248$. 